\title{
Neuropathy with Onion Bulb Formations and Pure Motor Manifestations
}

\author{
Roland N. Auer, Robert B. Bell and Mary Anne Lee
}

\begin{abstract}
A thirty-eight-year-old man presented with a six year history of symptoms resembling an anterior horn cell disorder. There was progressive upper extremity wasting and weakness in the absence of sensory complaints. Electrophysiologic abnormalities were confined to motor nerve conduction and indicated a demyelinating process involving the brachial plexus and major proximal upper extremity nerve trucks bilaterally. Biopsy of the proximal right ulnar nerve revealed changes suggesting a chronic demyelinating process, and onion-bulb formations were present. Immunohistochemical staining for S-100 protein was positive in the cells comprising the onion-bulbs, indicating a Schwann cell, not a perineurial origin of these cells. After 8 years, symptoms have failed to appear in the lower limbs. Recent reports in the literature have begun to delineate the syndrome, which appears to represent an unusual, localized or multifocal, sometimes inflammatory, clinically benign neuropathy that can mimic motor neuron disease in its earlier stages. We report the first such case with underlying pathology.
\end{abstract}

RÉSUMÉ: Neuropathie avec formations en bulbe d'oignon et manifestations cliniques exclusivement motrices Un homme âgé de trente-huit ans s'est présenté avec une histoire de symptômes ressemblant à une maladie des cellules de la corne antérieure, d'une durée de six ans. Il existait une atrophie progressive au niveau des membres supérieurs ainsi qu'une faiblesse sans symptômatologie sensitive. Les anomalies électrophysiologiques étaient limitées à la conduction motrice et indiquaient un processus démyélinisant impliquant le plexus brachial et les troncs nerveux majeurs des deux membres supérieurs. Une biopsie du nerf cubital proximal droit a montré des changements suggérant un processus démyélinisant chronique et la présence de formations en bulbe d'oignon. Une coloration immuno-histochimique pour la protéine S-100 était positive dans les cellules contenant des bulbes d'oignon, indiquant que ces cellules originaient des cellules de Schwann et non de l'épinèvre. Après 8 ans d'évolution, les symptômes ne sont pas présents dans les membres inférieurs. Des publications récentes tentent de caractériser ce syndrome, qui semble représenter une neuropathie inhabituelle, localisée ou multifocale, parfois inflammatoire, cliniquement bénigne, pouvant donner le change pour une maladie du neurone moteur au tout début. Nous rapportons le premier cas appuyé par une étude anatomo-pathologique.

Can. J. Neurol. Sci. 1989; 16:194-197

Wasting and weakness, in the absence of sensory symptoms, are usually indicative of anterior horn cell disease. We report a case where the clinical history and physical examination suggested the possibility of motor neuron disease, but electrophysiologic and pathologic studies showed evidence of a chronic demyelinating process, with onion bulb formations.

\section{Case Reports}

A thirty-eight-year-old man presented with a six-year history of progressive muscle wasting and weakness of the upper extremities. Initial manifestations were confined to ulnar innervated intrinsic hand muscles on the right but later came to also involve median innervated muscles. Approximately two years after the onset, both ulnar and median nerve distributions on the left became similarly affected. He continued to progress, but 8 years after onset of disease, symptoms and signs have remained confined to the upper extremities. Useful function of his hands was lost. He had no sensory complaints. The family history was unremarkable. He had no history of exposure to occupational or environmental toxins.
Examination revealed marked wasting and weakness of ulnar innervated intrinsic hand muscles bilaterally, and to a lesser degree, median innervated hand muscles. He had mild weakness of wrist flexion and extension, finger flexion and extension and, on the left side only, slight weakness of biceps, triceps and infraspinatus. Reflexes were $2^{+}$and symmetrical in his upper extremities and no fasciculations were seen. Sensory examination in his upper extremities was normal. Motor, reflex and sensory examination in his legs were normal. There was no palpable enlargement of any subcutaneous nerves.

\section{Laboratory and Electrophysiological Study}

Nerve conduction studies were performed. Conduction block was assessed using the percent change in amplitude and area of the compound muscle action potential between proximal and distal stimulation sites. The finding of conduction block is indicative of proximal demyelination with intact distal axons.

Sensory nerve action potentials recorded orthodromically at the wrist for the ulnar and median nerves and antidromically at the ankle for the sural nerve showed normal latencies and

From the Departments of Pathology and Clinical Neurosciences, University of Calgary, Calgary

Received May 30, 1988. Accepted in final form January 5, 1989

Reprint requests to: Dr. R.N. Auer, Neuropathology, Health Sciences Center, 3330 Hospital Dr. N.W., Calgary, Alberta, Canada T2N 4N1 
amplitudes. Motor conductions were slowed in median and ulnar nerves bilaterally with velocities mildly affected in forearm segments but more profoundly affected in the elbow to axillary segments. Responses were obtained from the abductor pollicis brevis for the median nerve and abductor digiti minimi for the ulnar nerve. There was a marked degree of conduction block proximally in affected nerves. F-wave latencies from both median and ulnar nerves were markedly prolonged. Nerve conduction studies of his lower extremities, including $f$-wave latencies, were normal.

Electromyography (EMG) of affected muscles demonstrated evidence of chronic neurogenic change evidenced by large, long duration, polyphasic motor unit potentials with marked loss of motor unit potentials. Fibrillation potentials were seen in the severely affected muscles, but fasciculations were distinctly rare. In muscles which appeared minimally affected, there was evidence of neurogenic motor unit potentials but no denervation. EMG examination of paracervical muscles was normal. The tibialis anterior muscles showed a few large, long-duration potentials but no active denervation and normal recruitment of motor units. Representative motor nerve conduction parameters from the left arm are shown in Table 1. Similar changes to those demonstrated on the left were present on the right.

Other investigations included a complete myelogram, CT scan of brachial plexus, chest X-ray, thyroid studies, serum protein electrophoresis, CBC and differential, ESR, $\mathrm{C}_{3}$ and $\mathrm{C}_{4}$, rheumatoid factor, antinuclear antibody, serum $B_{12}$, hexosaminidase assay, urinary porphyrin and heavy metal screen, all of which were normal. Cerebrospinal fluid analysis was also normal with a protein content of $0.27 \mathrm{~g} / \mathrm{L}$.

Table 1: Motor Conduction Studies*

\begin{tabular}{lcccc}
\hline $\begin{array}{l}\text { Stimulation } \\
\text { Position } \dagger\end{array}$ & $\begin{array}{c}\text { Latency } \\
\text { (m/sec) }\end{array}$ & $\begin{array}{c}\text { Standard } \\
\text { Deviations } \\
\text { From Normal }\end{array}$ & $\begin{array}{c}\text { Amplitude } \\
\text { (mv) }\end{array}$ & $\begin{array}{c}\text { Area } \\
(\mathbf{m v} \cdot \mathbf{m s})\end{array}$ \\
\hline Median, wrist & 5.2 & $* 3.4$ & 6.2 & 23.3 \\
Median, elbow & 10.9 & & 3.2 & 12.8 \\
Median, axilla & 16.0 & & 0.6 & 0.5 \\
Ulnar, wrist & 5.6 & $* 6.0$ & 2.5 & 10.0 \\
Ulnar, elbow & 11.6 & & 2.5 & 11.5 \\
Ulnar, axilla & 16.0 & & 1.3 & 5.6
\end{tabular}

\begin{tabular}{lcccc} 
Segments & $\begin{array}{c}\ddagger \\
\mathbf{C V} \\
(\mathbf{m} / \mathbf{s})\end{array}$ & S.D. & $\begin{array}{c}\text { \% Ampl } \\
(\mathbf{1 - 2})\end{array}$ & $\begin{array}{c}\| \\
\text { \% Area } \\
(\mathbf{1 - 2})\end{array}$ \\
\hline L median wrist - L median elbow & 43.9 & -2.9 & -48 & -45 \\
L median elbow - L median axilla & 39.2 & -3.9 & -80 & -96 \\
L ulnar wrist - L ulnar elbow & 51.7 & & 0 & 16 \\
L ulnar elbow - L ulnar axilla & 35.2 & -4.8 & -47 & -52
\end{tabular}

F wave latencies

\begin{tabular}{lll} 
& & $\mathbf{5 0}$ \\
\hline L median & $49.2 \mathrm{msec}$ & +15.8 \\
L ulnar & $47.2 \mathrm{msec}$ & +15.3 \\
\hline
\end{tabular}

\footnotetext{
* Left upper limb

$\dagger$ nerve, location of stimulus

$\ddagger$ conduction velocity

$\S$ per cent amplitude change

\| per cent area change
}

\section{Nerve Biopsy}

Biopsy of the right ulnar nerve high in the axilla was performed (F.H. NS-2225-86), since pathology was suspected in that location, and since useful function of that nerve had already been lost. Portions of the specimen were processed in graded ethanols and embedded in paraffin for light microscopy and immunohistochemistry. Small samples for electron microscopy were embedded in epoxy resin. Thick sections were stained with toluidine blue for light microscopy, and thin sections were stained with uranyl acetate and lead citrate before examination in a Hitachi 600 electron microscope. Light microscopy showed over half the cross-sectional area of the nerve to be normal, with geographic patches of thinly myelinated large axons and onion bulb formations (Figure 1). Individual axons surrounded by onion bulbs were occasionally seen remote from these areas. $S$ 100 immunohistochemical staining was positive in these cells surrounding the axons, indicating them to be Schwann cells, not perineurial cells. Nerve fiber loss was minimal. There was no inflammation, and blood vessels were normal.

Electron microscopy revealed a lamellar arrangement of Schwann cells around thinly myelinated axons, forming onion bulbs (Figure 2).

\section{Discussion}

The presentation of this patient mimicked early motor neuron disease, but subsequent investigations revealed a neuropathy, remarkably restricted in its distribution. Two major points merit discussion: the pure motor involvement and the limitation of the disease to the brachial plexus.

Clinical manifestations in this case were confined to the motor system of the upper limbs and electrophysiological studies localized the abnormality to the brachial plexus and major proximal nerve trunks of the upper extremities. The nerve roots were relatively spared, evidenced by a normal CSF protein and a normal paracervical EMG. The electrophysiological findings indicated a persistent proximal conduction block in the

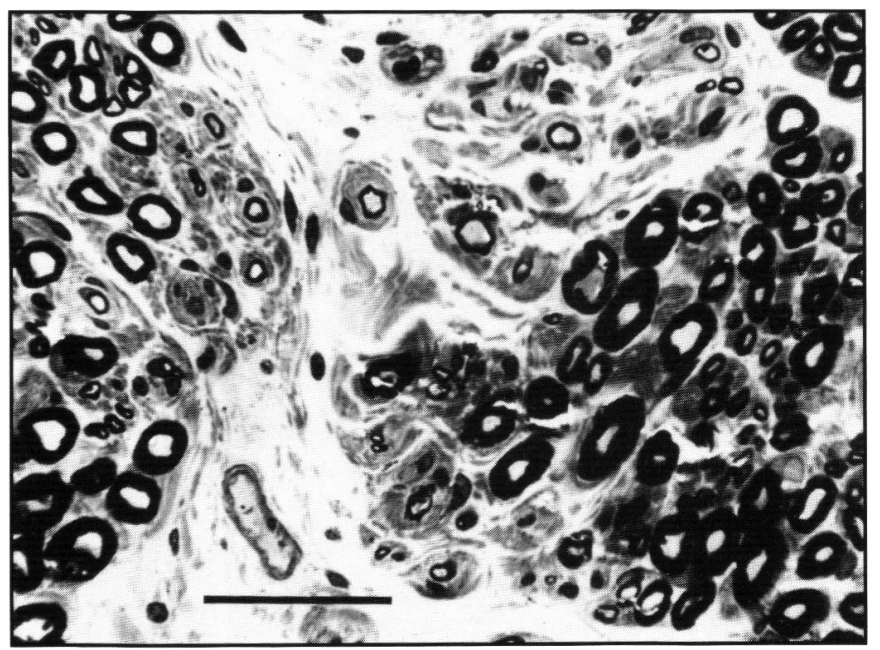

Figure I - Microscopic field from the biopsy of the ulnar nerve high in the axilla, demonstrating well demarcated areas where axons have thin myelin sheaths in relation to axonal caliber: Onion bulb formations are seen in these more loosely arranged areas of the nerve. Toluidine blue, Bar $=50 \mu \mathrm{m}$. 
brachial plexus and suggested a proximal demyelinating process with intact distal axons. However, in spite of the clinical and pathologic evidence for a demyelinating process, subsequent treatment of the patient with corticosteroids $(50 \mathrm{mg}$. prednisone daily for 3 months) produced no evidence of clinical or neurophysiological improvement, and the patient has continued to deteriorate.

The restriction of symptoms and signs to the motor system after a clinical course of 8 years would suggest, in the absence of other investigations, a form of motor neuron disease, rather than a peripheral neuropathy. A precedent for neuropathy selectively affecting motor elements while largely sparing senory elements exists in the acute and chronic inflammatory polyradiculoneuropathies. Multifocal, demyelinating neuropathy showing predominantly upper limb involvement has been described, but with a mixture of motor and sensory symptoms. ${ }^{1}$ Conduction block and pathological evidence of demyelination were shown.l Focal hypertrophic neuropathies primarily localised to the brachial plexus have been reported, 2 but with inflammation, and a mixed sensorimotor clinical picture. An inflammatory neuropathy was recently reported in a 34-year-old woman, with multifocal conduction block. ${ }^{3}$ Although onion bulb formations were seen, as in the present case, the involvement of all 4 limbs, the presence of inflammation and the lack of any resemblance to motor neuron disease in the clinical presentation contrast with the present case.

Cases more closely resembling the present one have been described, with histories suggesting motor neuron disease. ${ }^{4,5}$ Electrophysiologic studies have shown evidence of demyelination or conduction block, with a clinical course that was either progressive, ${ }^{6}$ plateaued or showed actual improvement. 4.7 The authors of these reports have recognized the ability of demyelinating neuropathy to mimic the early stage of motor neuron disease.

Pathologically, the demonstration of axons thinly myelinated in relation to their size, and the finding of onion bulb forma-

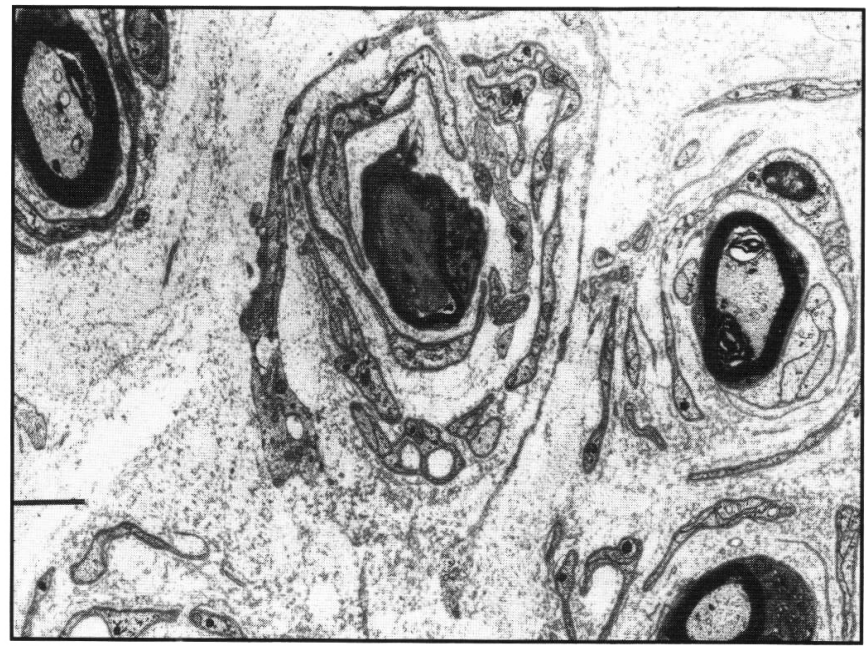

Figure 2 - Electron microscopy show's axons with surrounding Schwann cell processes in concentric rings, forming onion bulbs. Axons in these regions show thin myelin sheaths in relation to their diameter. Excess collagen is present. Uranyl acetate and lead citrate. Bar $=5 \mu \mathrm{m}$. tions, suggest repeated episodes of demyelination and remyelination as an ongoing process in this disease. There is experimental evidence from more than one animal model that repeated cycles of demyelination and remyelination play a role in the pathogenesis of onion bulb formation. $8-10$ In some clinical cases, possibly related to the present one, intense mononuclear inflammation has been seen, likely due to autoimmunity or viral infection." The intensity of the lymphohistiocytic inflammation, which included germinal centers, as well as the tumor-like proliferation of Schwann cells, clearly set such cases of hypertrophic brachial plexus neuritis 11 apart from the present case. Nevertheless, the case reported here may represent a more chronic, slowly progressive form of hypertrophic brachial plexus neuritis, with inflammation having been either missed on biopsy, or absent altogether.

A related disorder, a diathesis of perineurial cells, should be mentioned if only to distinguish it pathologically from the present condition. Recently, it has become recognised that proliferations of perineurial cells can occur in nerve, clinically showing some features of hypertrophic onion-bulb neuropathy. ${ }^{12.13}$ Immunochemistry is more useful than electron microscopy in distinguishing this condition from the present one, S-100 staining being uniformly negative in the perineurial cells of "perineurioma", 14.15 but positive in the Schwann cell onion-bulbs of hypertrophic neuropathy. ${ }^{13,16,17}$

The etiology of demyelination in the present case remains obscure. It is possible that this represents a variant of chronic inflammatory demyelinating polyradiculoneuropathy demonstrating an unusual susceptibility of motor fibres within the brachial plexus, and that location of the biopsy missed the inflammation. Whatever the etiology, it is important to note that demyelinating peripheral neuropathy with a remarkably restricted distribution can resemble motor neuron disease in its clinical presentation.

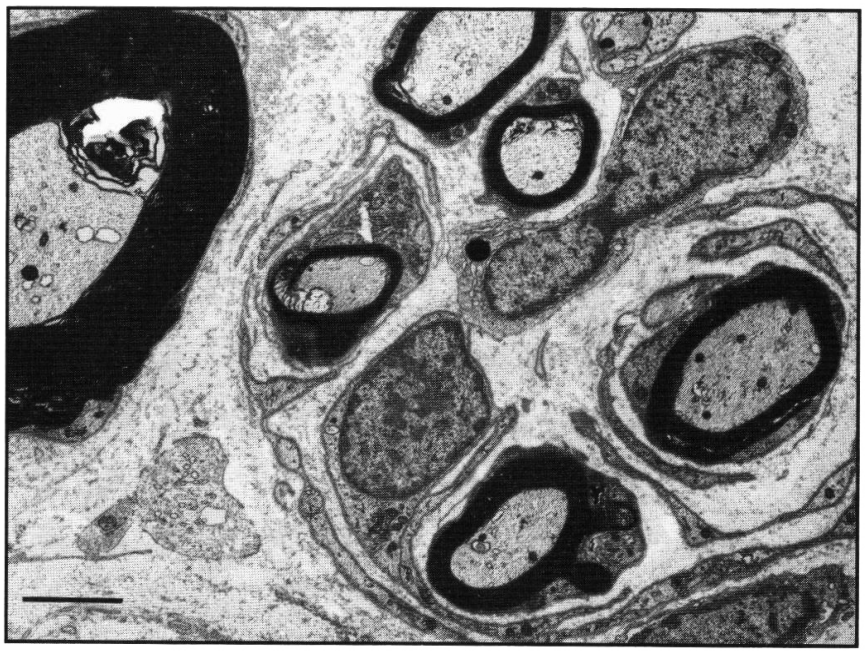

Figure 3 - An axon with a myelin sheath of normal thickness is shown on the left, with thinly myelinated axons and several concentrically arranged Schwann cells seen in the center and right. Uranyl acetate and lead citrate. $B$ ar $=5 \mu \mathrm{m}$. 


\section{ACKNOWLEDGEMENT}

The typing expertise of Ms. Edie Tingle is appreciated by the authors.

\section{REFERENCES}

1. Lewis RA, Summer AJ, Brown MJ, et al. Multifocal demyelinating neuropathy with persistent conduction block. Neurology (NY) 1982; 32: 958-964

2. Adams RD, Asbury AK, Micklesen JJ. Multifocal pseudohypertrophic neuropathy. Trans Amer Neurol Assoc 1965; 90: 30-34.

3. Bradley WG, Bennett RK, Good P, et al. Proximal chronic inflammatory polyneuropathy with multifocal conduction block. Arch Neurol 1988; 45: 451-455.

4. Chad DA, Hammer K, Sargent J. Slow resolution of multifocal weakness and fasciculation: a reversible motor neuron syndrome. Neurology 1986; 36: 1260-1263.

5. Parry GJ, Clarke S. Multifocal acquired demyelinating neuropathy masquerading as motor neuron disease. Muscle Nerve 1988; 11 : 103-107.

6. Roth G, Rohr J, Magistris MR, et al. Motor neuropathy with proximal multifocal persistent conduction block, fasciculations and myokymia. Evolution to tetraplegia. Eur Neurol 1986; 25: 416423.

7. van den Bergh P, Logigian EL, Kelly JJ Jr. Motor neuropathy with multifocal conduction blocks. Muscle Nerve 1989; 11:26-31.
8. Dyck PJ. Experimental hypertrophic neuropathy: pathogenesis of onion-bulb formations produced by repeated tourniquet applications. Arch Neurol 1969; 21: 73-95.

9. Lampert PW, Schochet SS Jr. Demyelination and remyelination in lead neuropathy: Electron microscopic studies. J Neuropathol Exp Neurol 1968; 27: 527-545.

10. Weller RO, Das Gupta TK. Experimental hypertrophic neuropathy: an electron microscope study. J Neurol Neurosurg Psychiatry 1968; 31: 34-42.

11. Cusimano MD, Bilbao JM, Cohen SM. Hypertrophic brachial plexus neuritis: a pathological study of two cases. Ann Neurol 1988; 24: 615-622.

12. Bilbao JM, Khoury NJS, Hudson AR, et al. Perineurioma (Localized hypertrophic neuropathy). Arch Pathol Lab Med 1984; 108: 557-560.

13. Böker D-K, Schönberg F, Gullotta F. Localized hypertrophic neuropathy - a rare, clinically almost unknown syndrome. Clin Neuropathol 1984; 3: 228-230.

14. Tranmer BI, Bilbao JM, Hudson AR. Perineurioma: a benign peripheral nerve tumour. Neurosurgery 1986; 19: 134-137.

15. Ohno T, Park P, Akai M, et al. Ultrastructural study of a perineurioma. Ultrastruct Pathol 1988; 12: 495-504.

16. Gullotta $F$. Localized hypertrophic neuropathy: a perineurialoma? Clin Neuropathol 1985; 4: 92.

17. Vallat JM, Vital C. Localized hypertrophic neuropathy - a rare and clinically almost unknown syndrome. Clin Neuropathol 1986; 5: 230. 